\title{
RECENT GEOMORPHIC EVOLUTION OF THE FAN DELTA OF THE MORNOS RIVER, GREECE: NATURAL PROCESSES AND HUMAN IMPACTS
}

\author{
Karymbalis E. ${ }^{1}$, Gaki-Papanastassiou K. ${ }^{2}$, and Maroukian H. ${ }^{2}$ \\ ${ }^{I}$ Harokopio University, Department of Geography, karymbalis@hua.gr \\ ${ }^{2}$ National and Kapodistrian University of Athens, Faculty of Geology and Geoenvironment, \\ Department of Geography and Climatology,gaki@geol.uoa.gr,maroukian@geol.uoa.gr
}

\begin{abstract}
The Mornos river fan delta is located on the northern side of the western Gulf of Corinth is a Gilbert-type fan delta with an arcuate form characterised by the abundance of coarse sediments. In order to determine the processes which contributed in the configuration of the fan delta during the last two centuries a detailed geomorphic map was prepared depicting both the deltaic plain and the coastal zone features. Comparative examination of 1945, 1986 and 1998 aerial photographs and reliable maps of the last two centuries along with field observations detected recent changes of the fan delta. The construction of a dam in the upper reaches of the basin in 1980 has significantly decreased the sediment supply downstream and has slackened the growth of the fan delta. After 1980 the eastern distributary has been abandoned causing a $120 \mathrm{~m}$ retreat at the river mouth. Although a progradation rate of 4 $m / y e a r$ has been observed for the western active distributary in the period between 1945 and 1986, no remarkable changes have occurred since that period. Additionally, an assessment of the impact of the potential global future sea-level rise to the fan delta is attempted.
\end{abstract}

Key words: Coastal Geomorphology, Western Greece, Holocene.

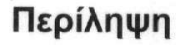

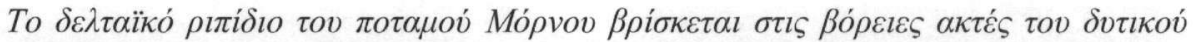

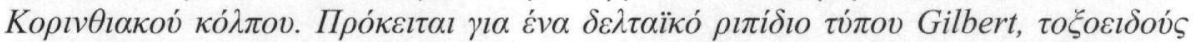

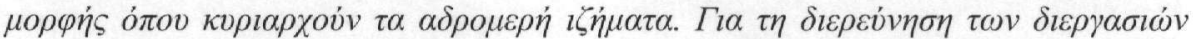

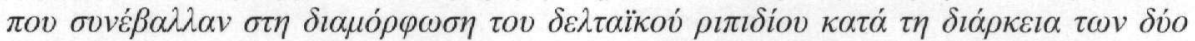

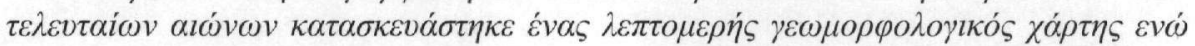

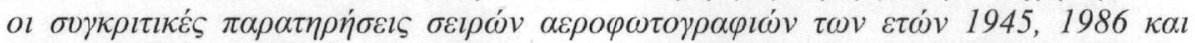

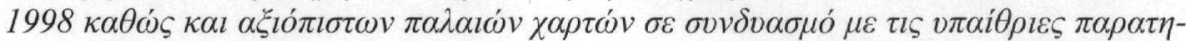

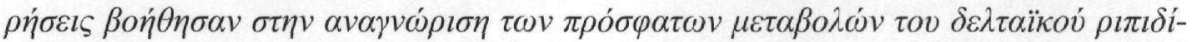

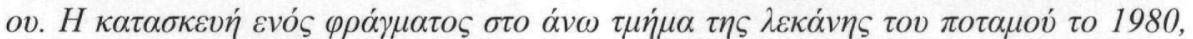

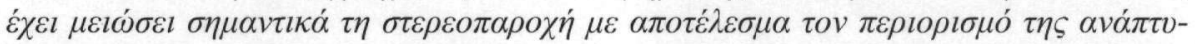

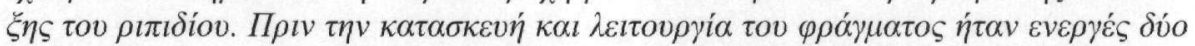

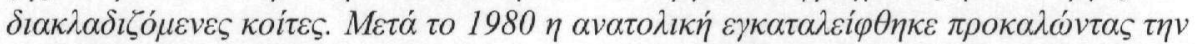

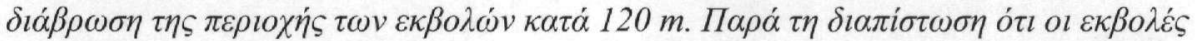

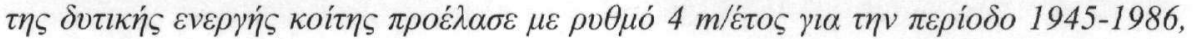




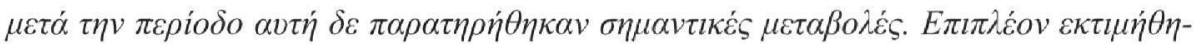

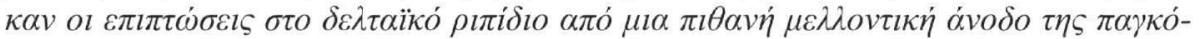

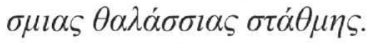

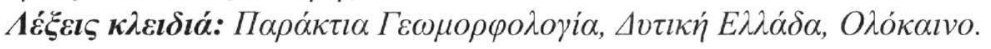

\section{Introduction}

River deltas are some of the most sensitive and complex environments at the land-sea interface due to many physical factors involved in their formation and evolution. They are of fundamental socioeconomical significance, attracting agricultural, rural, fishing and tourism activities.

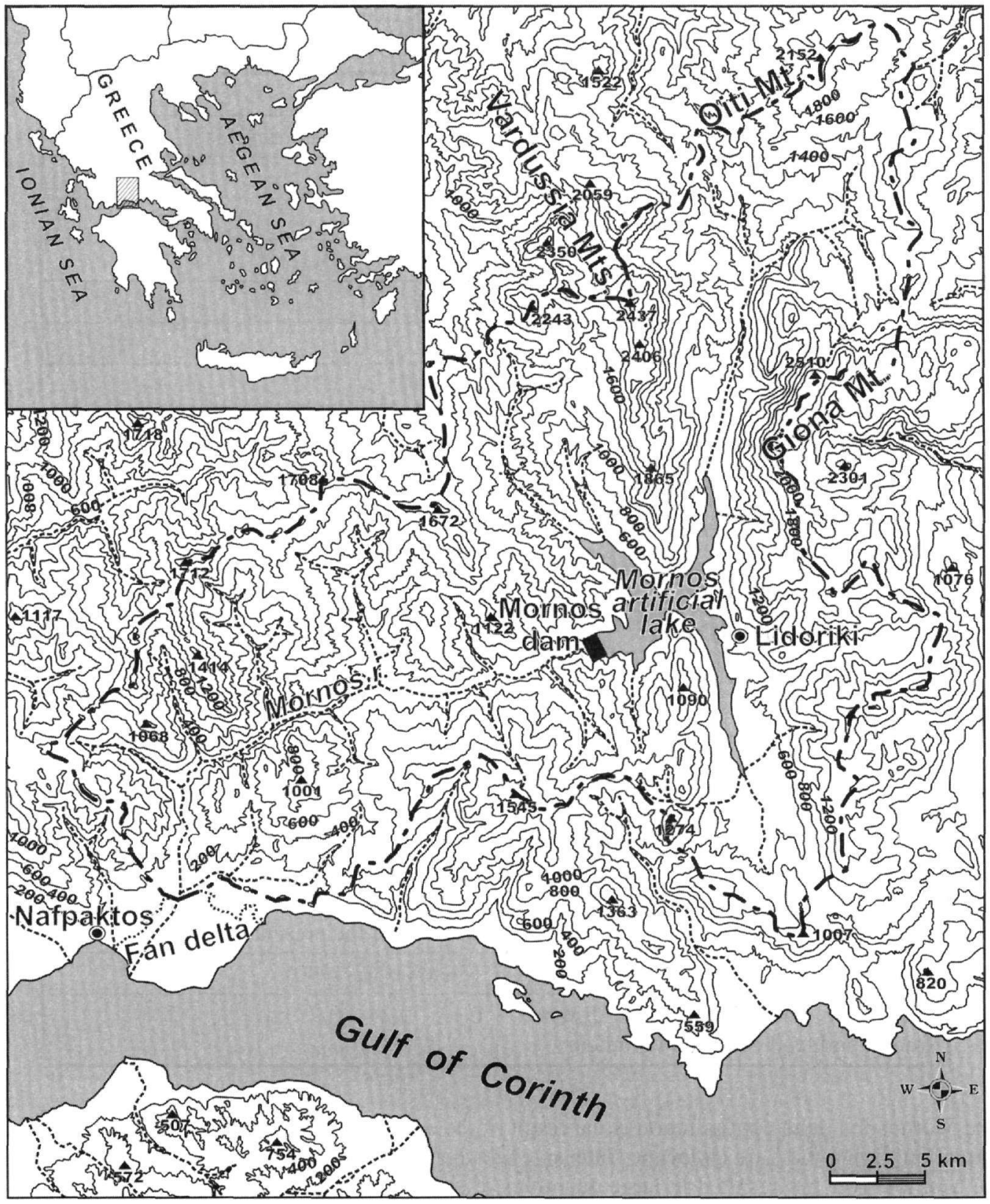

Figure 1 - Topographic map of the Mornos river drainage basin 
Greek deltas comprise important lowland areas where cultivation of various crops is important. Morphologically they have been studied extensively in recent decades (Zamani and Maroukian 1980, Piper and Panagos 1981, Psilovikos and Hahamidou 1987, Stournaras 1990, Poulos and Chronis 1997, Maroukian and Karymbalis 2004, Vott et al. 2004).

The Mornos river fan delta is located on the northern side of the western Gulf of Corinth (Fig. 1). It is a Gilbert-type fan shaped alluvial body with an area of $28 \mathrm{~km}^{2}$ and a mean gradient of $0.004 \%\left(0.2^{\circ}\right)$ (Table 1). It has an arcuate form and is characterised by abundant coarse sediments. According to the delta classification proposed by Galloway (1975), the Mornos delta should be classified among those affected mainly by fluvial sediment supply and wave activity.

Table 1 - Characteristics of the fan delta of the Mornos river concerning drainage basin, alluvial valley, deltaic plain and receiving basin.

\begin{tabular}{|l|l|}
\hline \multicolumn{2}{|c|}{ Drainage basin } \\
\hline Basin climate: & Temperate Mediterranean \\
\hline Rainfall: & $600-1200 \mathrm{~mm}$ \\
\hline Basin area: & $1010 \mathrm{~km}^{2}$ \\
\hline \multicolumn{2}{|c|}{ Alluvial valley } \\
\hline Main channel length: & $60 \mathrm{~km}$ \\
\hline Main channel gradient: & 1.17 \\
\hline & Deltaic plain \\
\hline Climate: & Mediterrannean \\
\hline Tectonic setting: & Subsiding asymmetric graben \\
\hline Delta area: & $28 \mathrm{~km}$ \\
\hline Channel length: & $5.63 \mathrm{~km}$ \\
\hline Channel gradient: & $0.42 \%$ \\
\hline Shoreline length/delta width: & $19.06 / 7.4=2.58$ \\
\hline Mean annual discharge: & $40 \mathrm{~m}^{3} / \mathrm{sec}$ \\
\hline Delta type: & Arcuate \\
\hline $\begin{array}{l}\text { Sinuosity index } \\
\text { (channel length/straight channel length) }\end{array}$ & 1.023 \\
\hline \multicolumn{1}{|c|}{ Receiving basin (Gulf of Corinth) } \\
\hline Basin geometry: & $\begin{array}{l}\text { Relatively narrow east-west running } \\
\text { open ended gulf with active subsidence } \\
\text { seaward of the present shoreline }\end{array}$ \\
\hline Tidal range: & $18 \mathrm{~cm}(1958-1990)$ \\
\hline $\begin{array}{l}\text { 10m, 20m and 50m isobath distances } \\
\text { from mouth and delta front gradient: }\end{array}$ & $0.13-0.24-0.91 \mathrm{~km}$ \\
\hline
\end{tabular}

The Mornos fan delta configuration is the result of the combination of suitable conditions for delta formation during the Late Holocene. Intensive weathering and erosion over the catchment area of the Mornos river has resulted in large quantities of sediments readily available for transportation. Furthermore, climate conditions (high mean annual precipitation especially between November 
and February) and favourable oceanographic characteristics of the receiving basin resulted in the fan delta formation.

The aim of this study is to determine the natural and anthropogenic processes which contributed in the recent configuration of the delta as well as to assess impacts of the potential future sea-level rise to the deltaic plain.

\section{Mornos river drainage basin}

The Mornos river is located in west central Greece and drains an area of $1010 \mathrm{~km}^{2}$ (Fig. 1). Its drainage basin is elongated and reaches an elevation of $2510 \mathrm{~m}$ at its eastern end. The Mornos river crosses the geotectonic zones of Parnassos and Pindus and empties into the gulf of Corinth.

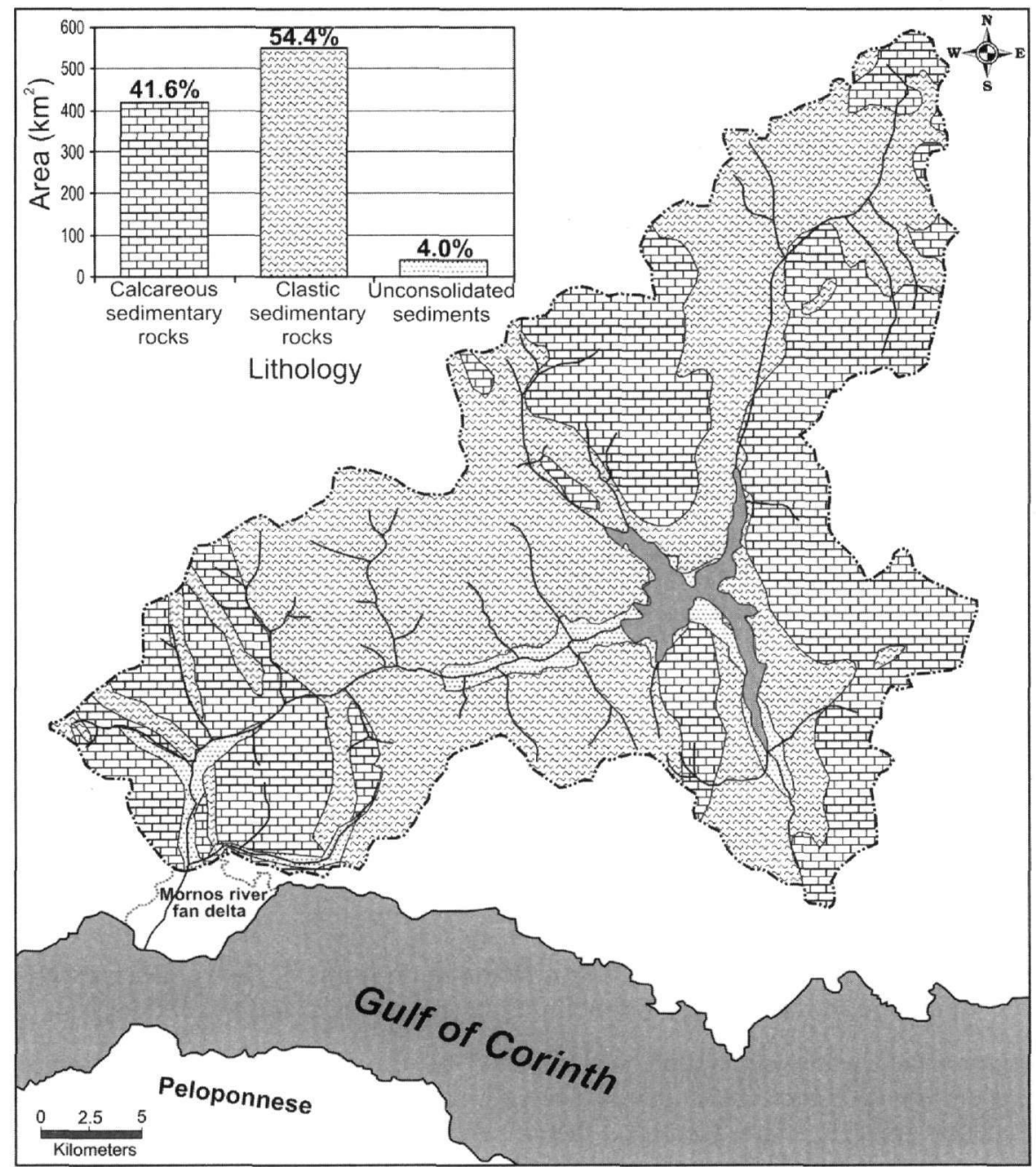

Figure 2 - Lithologic map of the Mornos river drainage basin with a diagram showing the participation of each one of the lithological types in the drainage basin area

Lithologically, the drainage basin consists of $54.4 \%$ clastic sedimentary rocks (mainly flysch formations), $41.6 \%$ of calcareous sedimentary rocks (mainly limestones) and $4.0 \%$ of unconsolidated fluvio-torrential sediments (Fig. 2). Tectonically, this area is affected by an older NW-SE trending fault system, contemporaneous to the Alpine folding, and a younger one having an E-W direction. The dendritic-trellis pattern of the Mornos drainage network reflects the influence of the 
geologic and tectonic regime of the broader area. The central part of the main channel of the Mornos river is affected by an E-W trending fault while a significant number of tributary streams follow NW-SE running faults, fold axes or lithologic contacts.

Mean annual precipitation ranges from $600 \mathrm{~mm}$ near the delta to more than $1200 \mathrm{~mm}$ in the northern and north-eastern highlands (Table 1). Mean annual temperature is about $14{ }^{\circ} \mathrm{C}$. Mean monthly annual discharge follows the mean monthly precipitation trend (the greatest flow is recorded during the winter months) while average mean annual discharge is $40 \mathrm{~m}^{3} / \mathrm{sec}$. Flow is now regulated by a dam constructed in 1980 in the upper reaches of the basin in order to supply Athens with potable water. It is estimated that the suspended sediment load of the Mornos river (prior to regulation due to the dam construction) was 0.5-0.8 tons $/ \mathrm{yr} / \mathrm{km}^{2}$ (Piper et al. 1990).

\section{Gulf of Corinth: the receiving basin}

The Gulf of Corinth (Fig. 3) is a major Late Cenozoic asymmetric graben (Brooks and Ferentinos 1984). Active faulting on the southern side of the gulf has resulted in more than $950 \mathrm{~m}$ of Pleistocene uplift of the mountains in the south. Maximum water depth in the gulf is $860 \mathrm{~m}$ located in the eastern basin. The Gulf of Corinth is characterised by high levels of seismicity and rapid extension rates of 15-22 mm/yr (Houghton et al. 2003). High seismic activity in the region is responsible for numerous submarine mass movements especially at the prodelta steep slopes mainly of northern Peloponnessus (Hasiotis et al. 2002, Poulos et al. 1996).

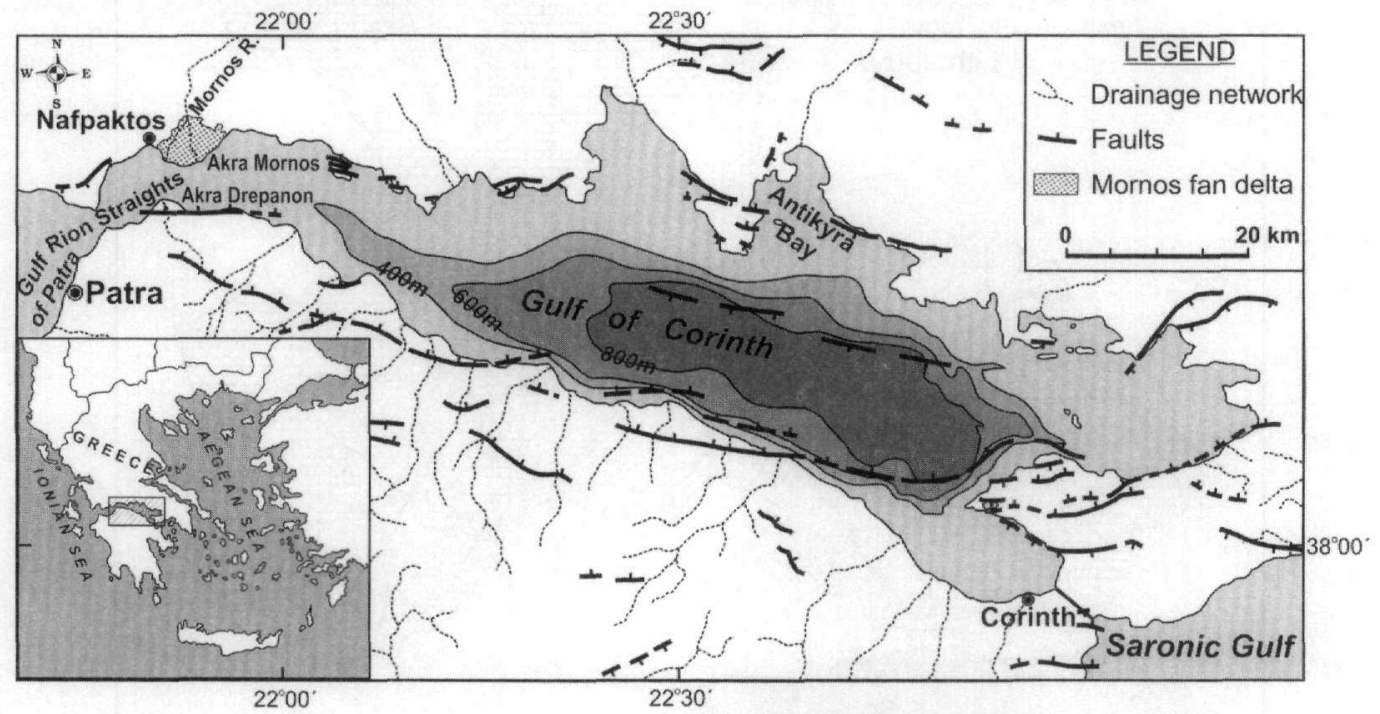

Figure 3 - Bathymetry of the Gulf of Corinth, the main faults of the broader area and the location of the Mornos river fan delta (based on Armijo et al. 1996)

The present surface water circulation is dominated by the funneling of both wind and water through the narrow Rion Straights and the adjacent western Gulf. Lascaratos et al. (1989), utilizing infrared satellite imagery, have identified the presence of an anti-clockwise gyre in the surface water circulation pattern of the central part of the Gulf, to the south of Antikyra Bay. Windinduced summer upwelling along the northern shoreline of the Gulf was also identified. Although the gulf can be characterized as a microtidal environment, with an average mean tidal range of 15 cm (Hydrographical Service of Navy 1991), tidal currents through the Rion Straights and between Akra Drepanon and Akra Mornos (Fig. 3) reach velocities of over $100 \mathrm{~cm} / \mathrm{sec}$. The funnelling also results in a highly bimodal distribution of predominant $\mathrm{E}$ or the WSW wind directions (Piper et al. 1990). The fetch from the east is much greater than from the SSW, since the Rion Straights minimize the passage of waves from the Gulf of Patras. Thus east facing coastlines are exposed to 
long fetches and periods of persistent strong winds, in contrast to short fetches and short duration of strong winds on west facing coasts (Piper et al. 1982).

\section{Methodology}

In the present study topographic sheets at a scale of 1:5000 were used in the field to prepare a detailed geomorphic map (Fig. 4) depicting deltaic features in order to determine the dominant morphodynamic processes responsible for the configuration of the deltaic environment. Additionally, aerial photograph series taken in 1945, 1986 and 1998 at scales of 1:42000, 1:33000 and 1:40000 respectively, were used together with old maps of 1852 and 1885 in an attempt to define diachronic changes along the deltaic plain and the coastal zone of the fan delta. All aerial photographs were geometrically corrected using image to image technique. Aerial photographs were matched and a mosaic image was created for each period. The mosaic data were manipulated in a GIS and three different coverages were created by digitizing the shorelines of the three different years. These were overlapped in order to detect shoreline changes during the period 1945-1998.

One of the dominant factors for the future evolution of the fan delta is the anticipated sea level rise. In order to quantify the implications for the deltaic coastal zone, the low-lying areas within the elevation zones of $0-0.5,0-1$ and $0-2 \mathrm{~m}$ were calculated. In addition, land uses for these zones were defined, mapped and estimated.

A spatial database derived from detailed analogue maps, geometrically corrected aerial photographs and field work, was constructed using GIS. Data procedure in the analytical context of GIS provided data integration which includes a common geographical reference system, common spatial and temporal coverage, and similar scale and quality of the data.

\section{Geomorphological observations}

\subsection{Geomorphology of the deltaic plain}

The Mornos river has a braided gravel channel aligned and enclosed by artificial levees along its entire delta length to its present mouth in the western part of the fan delta (Figs 4, 5). The 1945 aerial photographs show that there were two active distributaries.

The main channel was located in the central southeastern part of the delta plain while the present river channel was a lesser distributary. The eastern distributary channel had a more meandering pattern and was passing through the centre of the deltaic plain discharging at Bouka Karahassani, $3.7 \mathrm{~km}$ east of the present active river mouth (Figs 4,6 ). This channel was partially abandoned after the artificial alignment of the now active channel which took place in 1961. Following the construction of the dam in the upper reaches of the drainage basin in 1980, the sediment supply decreased significantly downstream and this channel has been totally abandoned.

Older abandoned channels are visible mainly in 1945 aerial photographs. They were mapped and grouped in four systems. Most of these abandoned channels begin from the apex of the fan delta leading to the present shoreline and can be relatively dated according to their distinctness.

Old maps of 1852 and 1885 show that there was one active distributary located in the western part of the delta during that period (Fig. 7). This now abandoned channel lies about $0.6 \mathrm{~km}$ west of the present artificially aligned channel. In the 1885 map flooded abandoned channels are also visible in the central part of the deltaic plain.

Another abandoned channel system begins from the apex of the fan delta ending southeast of Managouli village about $1.9 \mathrm{~km}$ northeast of the Bouka Karahassani mouth and seems to be older than that since it has undergone intense retreat due to marine erosion. 


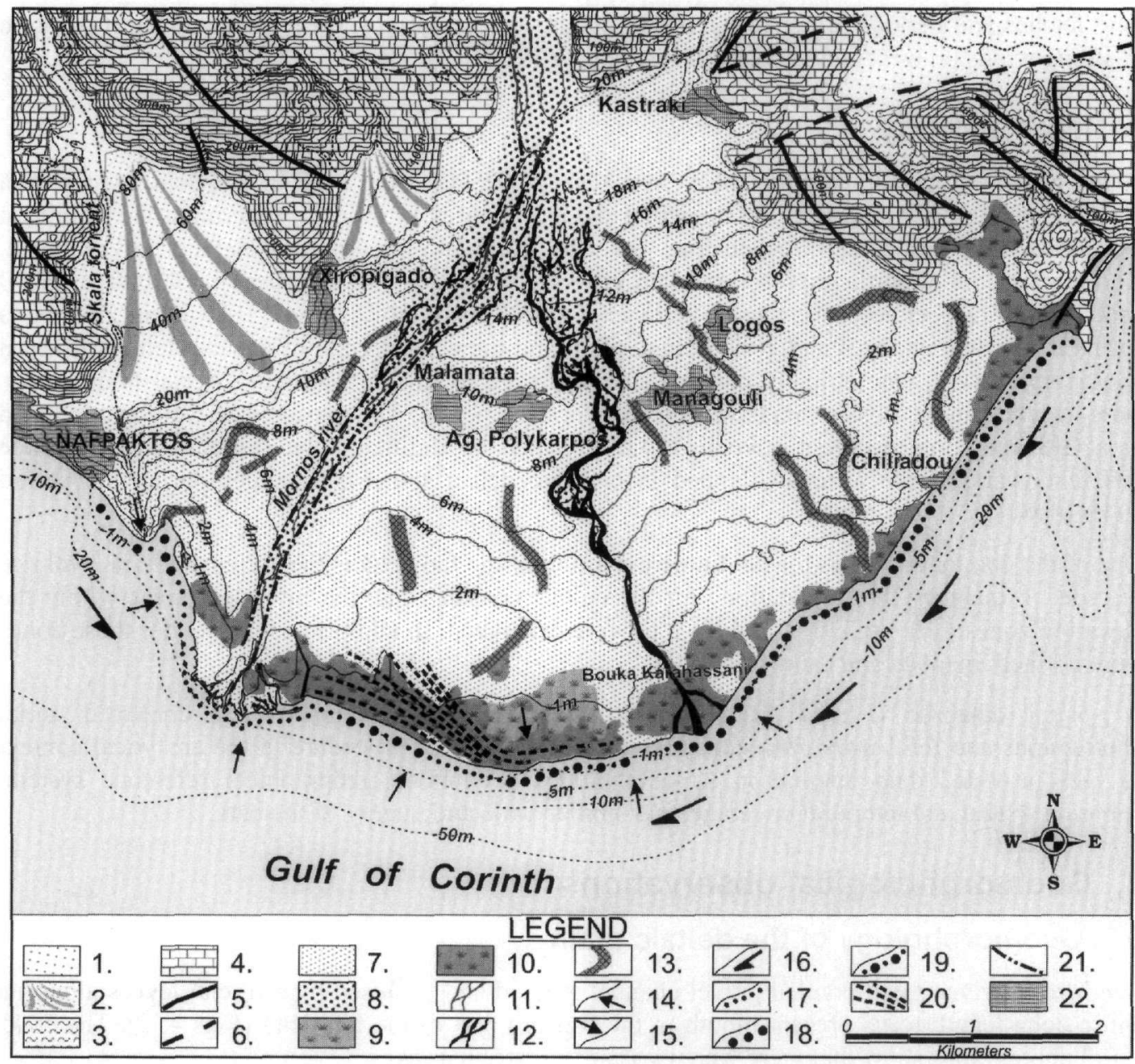

Figure 4 - Geomorphological map of the Mornos river fan delta. The map was prepared at the scale of 1:5000 and is based on field observations and the interpretation of aerial photographs: 1. Alluvial deposits, 2. Alluvial cones, 3. Flysch, 4. Limestones, 5. Visible fault, 6. Probable fault, 7. Deltaic plain deposits, 8. Channel deposits, 9. Seasonal marsh, 10. Permanent marsh, 11. Recent channel, 12. Most recently abandoned channel, 13. Abandoned channel, 14. Retreating coastline, 15. Prograding coastline, 16. Longshore currents, 17. Sandy beach, 18. Shingle gravelly beach, 19. Mixed particle beach, 20. Beach ridges, 21 . Artificial levee, 22. Human settlement

The easternmost channel system has a W.NW-E.SE direction north of Logos village leading to 0.5 $\mathrm{km}$ north of Chiliadou at the eastern end of the deltaic plain (Fig. 4). This channel maintains a meandering pattern for the last $1.4 \mathrm{~km}$ before reaching the shoreline. These traces seem to be the oldest visible distributary channels of the Mornos river fan delta.

The arcuate shape of the fan delta, the abandoned channels and the dominance of gravel suggests that delta growth took place by gradual shifting of braided distributaries. 


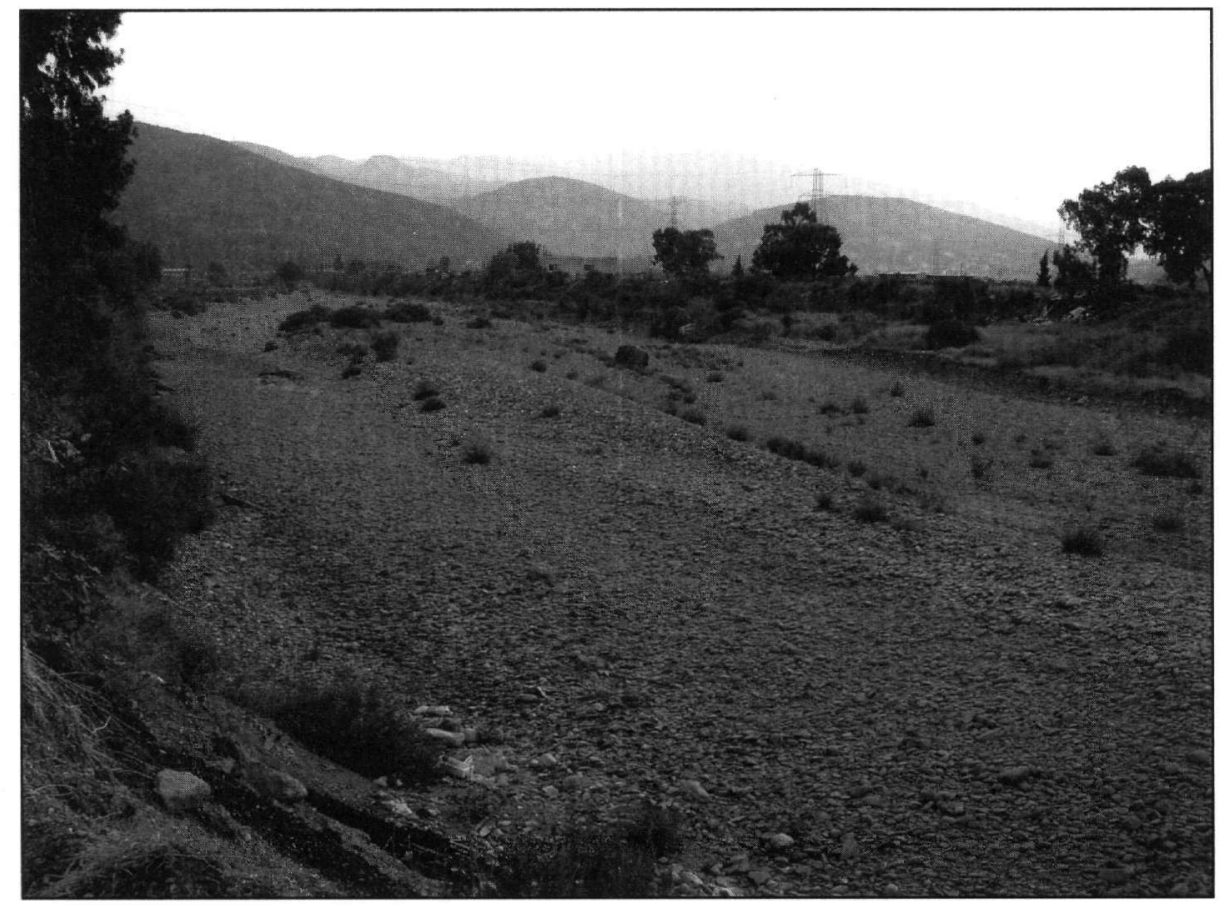

Figure 5 - View of the active braided channel at the apex of the fan delta

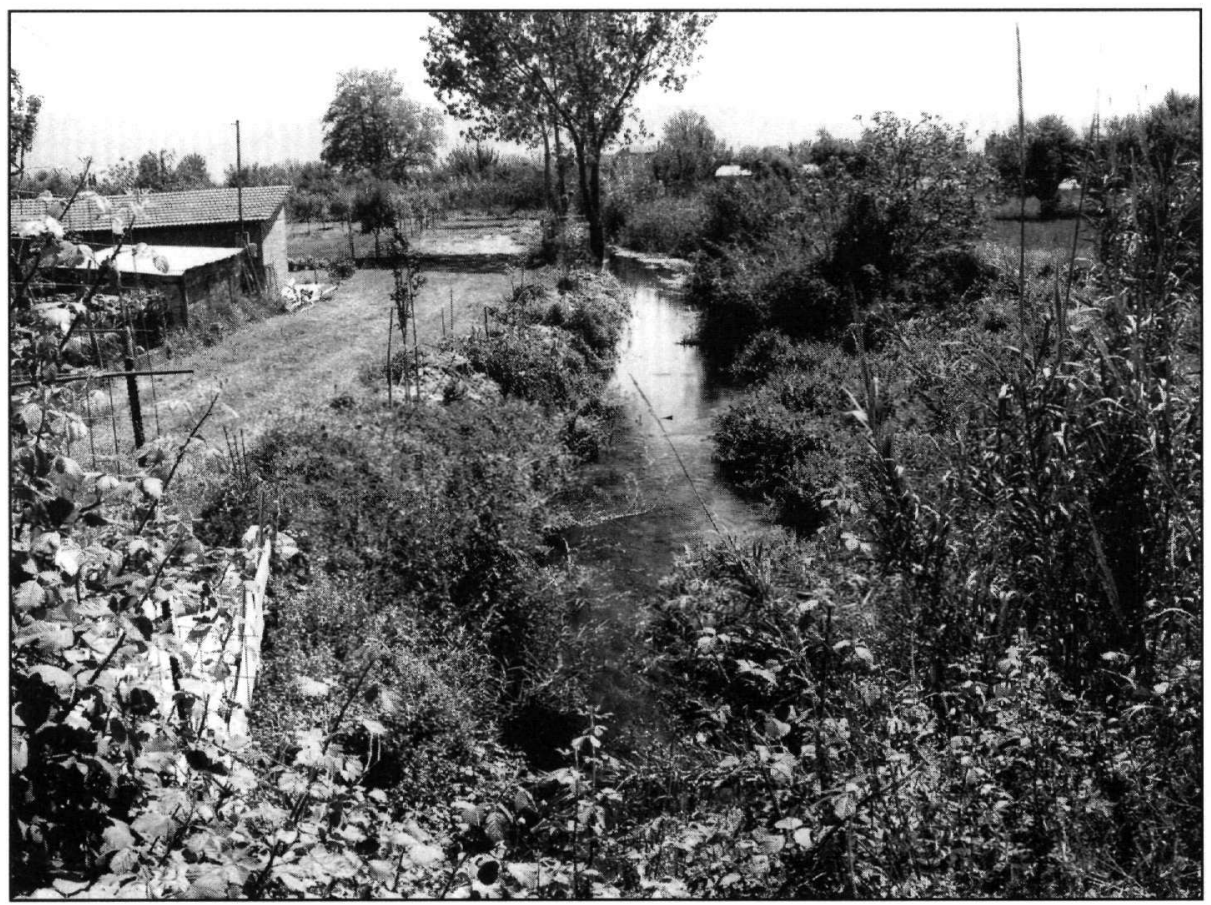

Figure 6 - The abandoned eastern distributary of the fan delta 

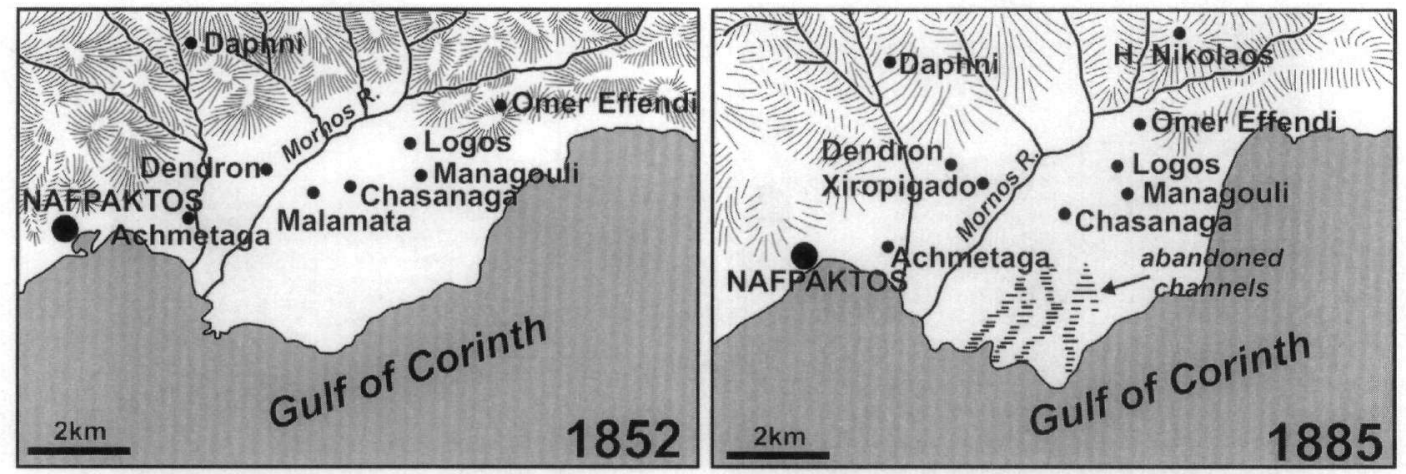

Figure 7 - Maps of 1852 and 1885 showing the Mornos river fan delta. The 1852 map is based on Carte de la Grèce at a scale 1:200,000, and the 1855 one is based on the topographic map of the K.u.K. Militär - Geographisches Institut at a scale 1:200,000
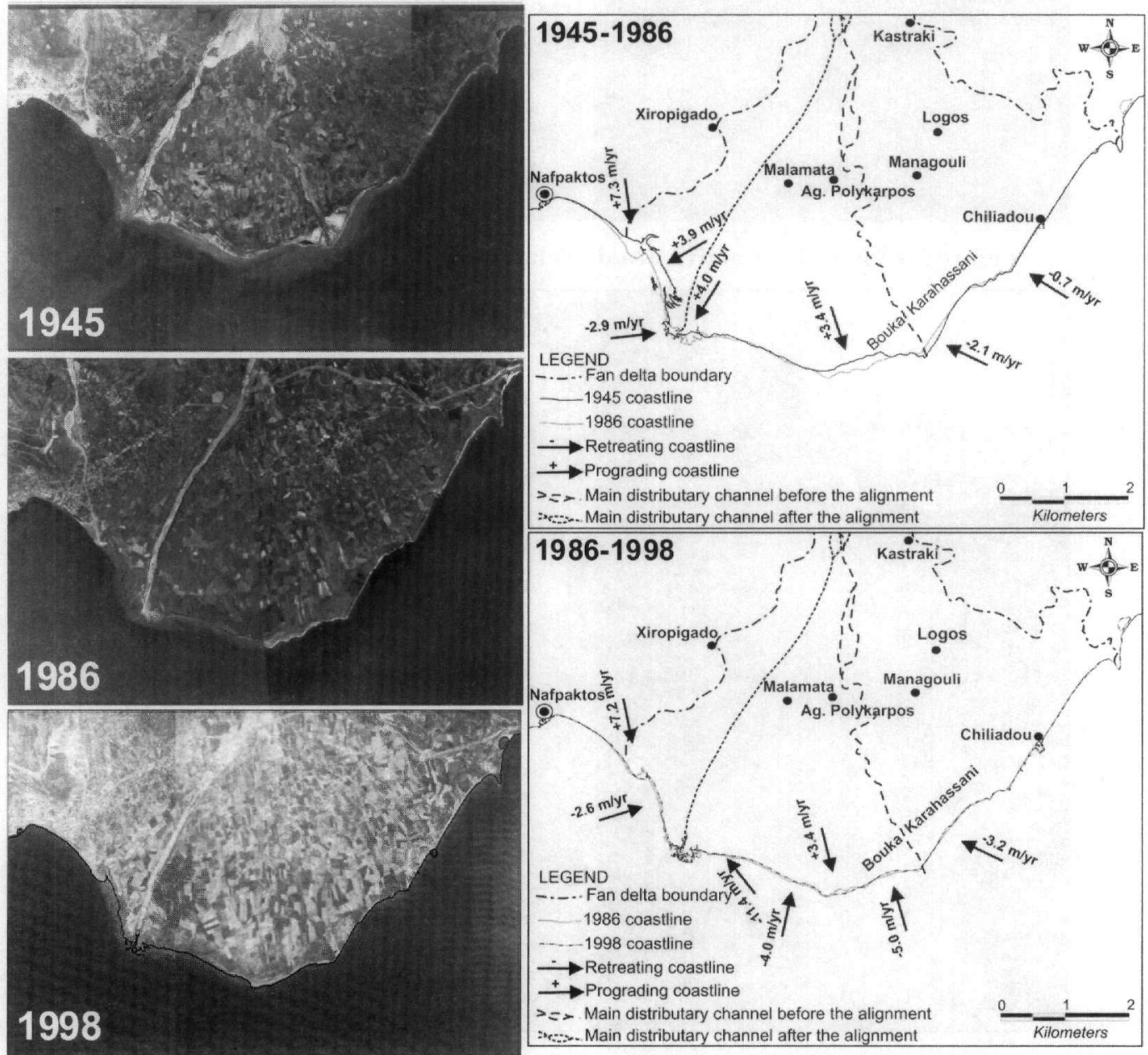

Figure 8 - Aerial photo-mosaic of the Mornos river fan delta of 1945, 1986 and 1998 respectively. Two maps were derived from the comparison of the aerial photographs and depict the evolution of the deltaic shore between 1945 - 1986 and 1986 - 1998 


\subsection{Geomorphology of the deltaic coastal zone}

The Mornos river deltaic coastal zone is characterized by the abundance of coarse grained sediments (gravels and pebbles). Sand and some fine gravel are transported eastwards from the mouth by longshore drift forming a series of small spits. At the most recently abandoned mouth, in the central part of the delta, deltaic sediments have been reworked by wave activity and wind, to form a series of eight almost parallel beach ridges (Fig. 4) which are visible in 1945 aerial photographs. Thus their formation predates 1945.

Comparative observations of aerial photographs taken in various years show that the eastern coastline is retreating due to wave erosion (Fig. 8). Various structures mostly summer cottages have been constructed in a 100 meter-wide deltaic coastal zone especially east of the river mouth. Attempts have been made by local house and land owners to stop the advancing sea by throwing boulders along the eastern fan delta shoreline (Fig. 9). Storm ridges are developed up to the yard walls of the cottages during severe storm conditions. It is estimated that during the time period between 1945 and 1986 the eastern area, especially the region northeast of Bouka Karahassani, has retreated at a rate of up to $2.14 \mathrm{~m} / \mathrm{yr}$ (Fig. 8). This rate increased to $3.25 \mathrm{~m} / \mathrm{yr}$. during the following 12 years between 1986 and 1998 .

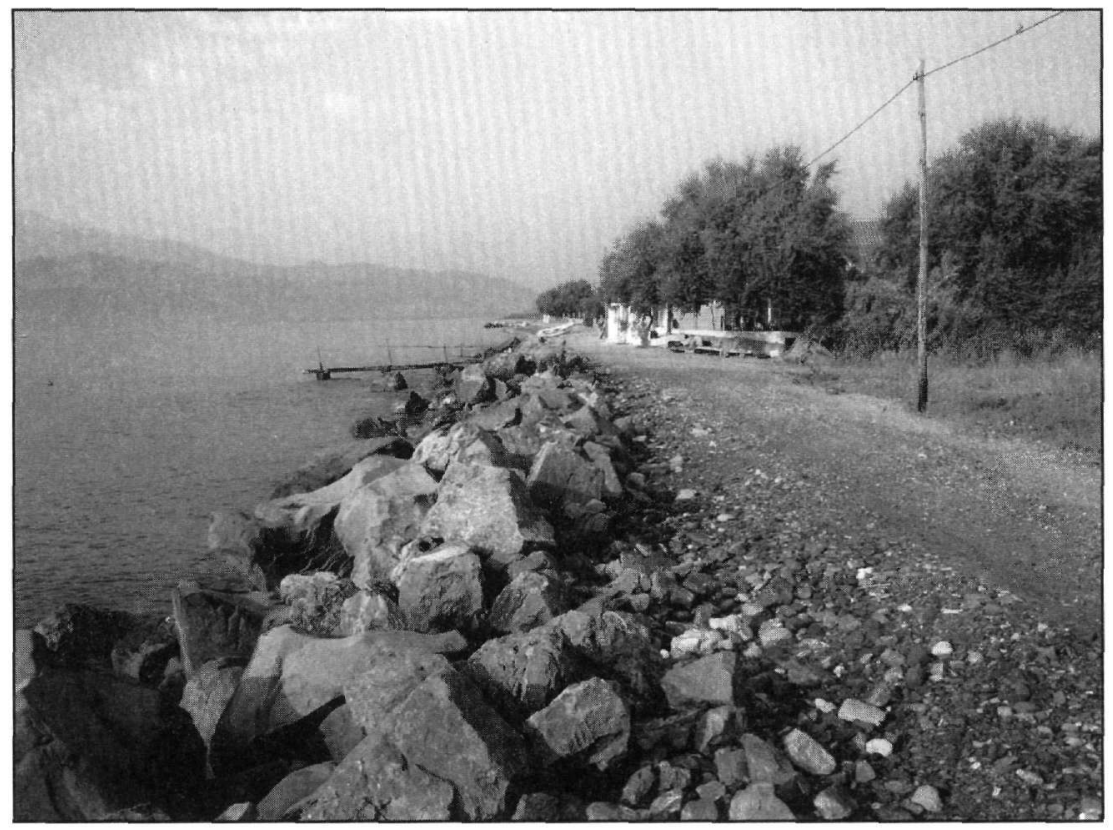

\section{Figure 9 - Boulders thrown along the eastern shore of the fan delta in order to stop the advancing sea}

The acceleration of the erosion rates for this part of the delta must have been caused by the wave activity and longshore currents immediately after the river changed its course to the west. The sediment derived from erosion has been reworked and transported westwards by longshore drift causing a coastline progradation of about $139 \mathrm{~m}$, which has built up an area of $0.14 \mathrm{~km}^{2}$ west of Bouka Karahassani (Fig. 8).

The coastline west of the present river mouth has advanced at a rate of $3.92 \mathrm{~m} / \mathrm{yr}$. between 1945 and 1986. Seaward progradation was the result of longshore drift and deposition of sediments delivered to the shore by both Mornos river and Skala torrent which has built a narrow and steep alluvial fan at the eastern flank of the delta (Fig. 4). This area seems to have slightly retreated for about $31.6 \mathrm{~m}$ between 1986 and 1998 probably due to the construction of the dam in the upper reaches of the basin since 1980 . The reduction of the sediment supply at the mouth has caused the 
retreat of the present mouth area for about $137 \mathrm{~m}$ which corresponds to a retreating rate of 11.41 $\mathrm{m} / \mathrm{yr}$. between 1986 and 1998 .

Nowadays the fan delta can be considered partially inactive being the coastal dynamic the only process that reworks the system.

\section{Implications of future sea-level rise}

A hazard that is expected to influence Mornos delta and most low-lying deltaic areas is the anticipated rapid sea-level rise triggered by the global climate warming (Gaki-Papanastassiou et al. 1997). The recent Intergovernmental Panel on Climate Change (2001) report estimates that sealevel will rise from 9 to $88 \mathrm{~cm}$ by the year 2100 . Such a sea-level rise could enhance the retreat of the Mornos delta coastline. The implications for the Mornos deltaic coastal sub-environments are assessed taking into consideration a $0.5 \mathrm{~m}, 1 \mathrm{~m}$ and an extreme $2 \mathrm{~m}$ potential rise of sea-level (Fig. 10, Table 2).

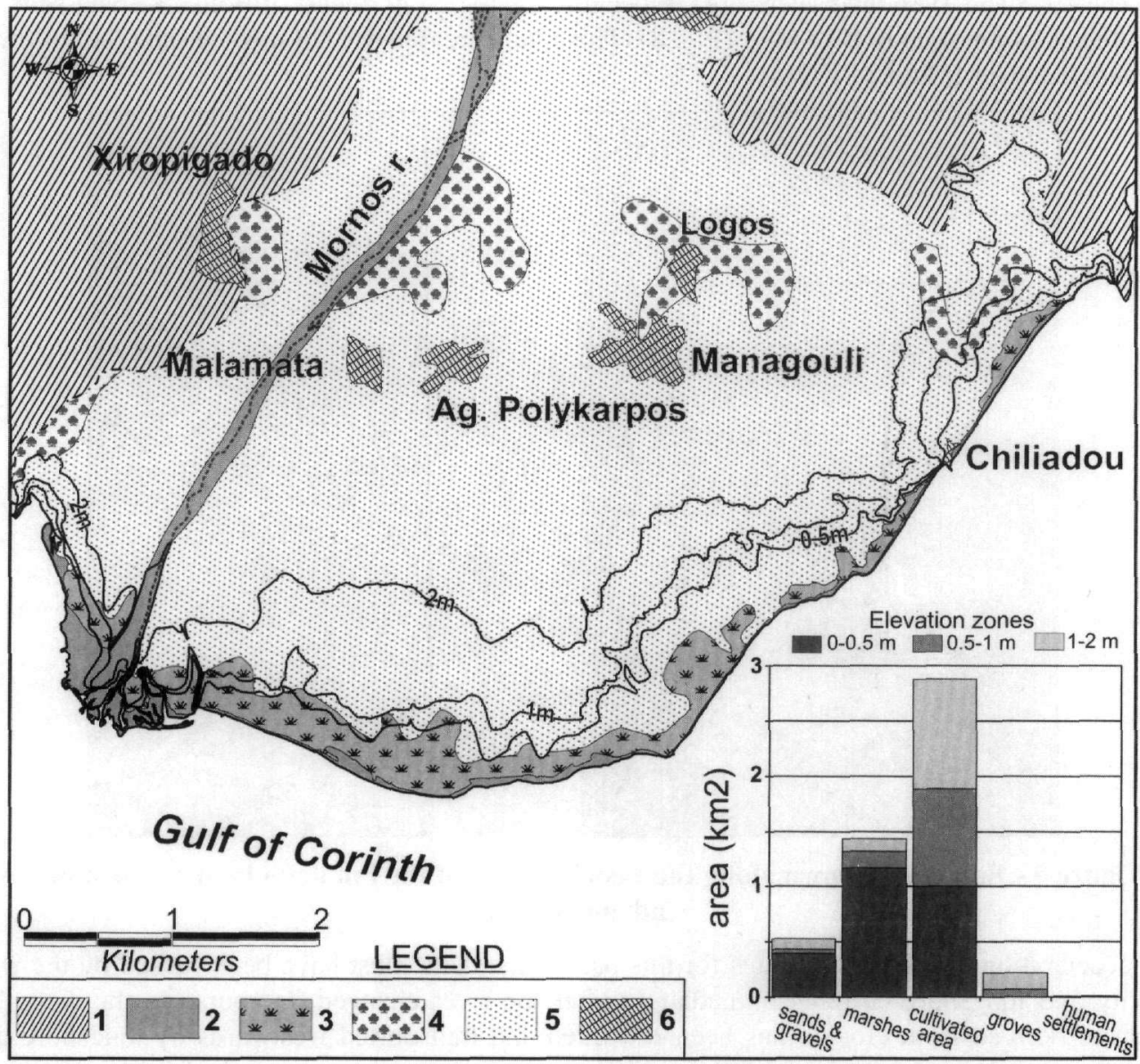

Figure 10 - Map portraying natural environments and land use of the low-lying areas of the fan delta. The diagram shows the distribution of the five land use classes for each elevation zone: 1. Bedrock, 2. Sands and gravels, 3. Marshlands, 4. Groves, 5. Cultivated area, 6. Human settlements

The area which will face severe problems due to the sea-level rise that lies below the contour line of $0.5 \mathrm{~m}$ is $2.58 \mathrm{~km}^{2}$ and corresponds to $9.2 \%$ of the total area of the delta (Table 2). Furthermore, the low-lying area below $1 \mathrm{~m}$ is $3.71 \mathrm{~km}^{2}$ while the deltaic region below the $2 \mathrm{~m}$ contour line is 
$7.25 \mathrm{~km}^{2}$ corresponding to $25.9 \%$ of the fan delta. Additionally, in an attempt to assess socioeconomic consequences, land uses that occupy the above potentially inundated elevation zones were identified and grouped in five classes including coastal and fluvial sandy and gravely sediments, cultivated areas, groves, human settlements and marshlands (Fig. 10). It is estimated that an extensive part of the low-lying deltaic coastal zone is occupied by economically important cultivations $\left(5.06 \mathrm{~km}^{2}\right.$ bellow $\left.2 \mathrm{~m}\right)$ as well as ecologically significant marshes $\left(1.42 \mathrm{~km}^{2}\right)$.

Table 2 - Area of land use categories for each elevation zone (in $\mathrm{km}^{2}$ ) for the low-lying region of the fan delta

\begin{tabular}{|l|l|l|l|}
\hline \multicolumn{1}{|c|}{ Land use } & \multicolumn{1}{c|}{$\mathbf{0 - 0 . 5} \mathbf{~ m}$} & \multicolumn{1}{c|}{$\mathbf{0 . 5 - 1} \mathbf{~ m}$} & \multicolumn{1}{c|}{$\mathbf{1 - 2} \mathbf{~ m}$} \\
\hline Coastal sands & $0.40 \mathrm{~km}^{2}$ & $0.03 \mathrm{~km}^{2}$ & $0.10 \mathrm{~km}^{2}$ \\
\hline Marshes & $1.17 \mathrm{~km}^{2}$ & $0.15 \mathrm{~km}^{2}$ & $0.11 \mathrm{~km}^{2}$ \\
\hline Cultivated area & $1.00 \mathrm{~km}^{2}$ & $0.88 \mathrm{~km}^{2}$ & $1.00 \mathrm{~km}^{2}$ \\
\hline Groves & $0.00 \mathrm{~km}^{2}$ & $0.07 \mathrm{~km}^{2}$ & $0.15 \mathrm{~km}^{2}$ \\
\hline Human settlements & $0.01 \mathrm{~km}^{2}$ & $0.00 \mathrm{~km}^{2}$ & $0.00 \mathrm{~km}^{2}$ \\
\hline Total area & $2.58 \mathrm{~km}^{2}$ & $1.13 \mathrm{~km}^{2}$ & $1.36 \mathrm{~km}^{2}$ \\
\hline
\end{tabular}

\section{Conclusions}

- Abandoned channels and the presence of coarse sediments along the shoreline indicate that the growth of the fan delta is the result of gradual shifting of numerous braided distributaries.

- The most discernible former channel trace is an abandoned almost straight braided channel west of the present distributary which is depicted in 1852 and 1885 reliable maps of Greece.

- Before the artificial alignment of the now active channel completed in 1961, two braided distributaries were active. After 1980, the eastern one was totally abandoned when a dam was constructed at the upper reaches of the basin.

- Today, coastal erosion is the main dominant geomorphic process along the fan delta coastline mainly due to the construction of the dam which has reduced drastically the sediment flux enhancing the wave activity effectiveness. The eastern coast, northeast of the most recently abandoned river mouth at Bouka Karahassani, has retreated about $86 \mathrm{~m}$ between 1945 and 1986 corresponding to a rate of $2.14 \mathrm{~m} / \mathrm{yr}$. Retreat rate accelerated to $3.25 \mathrm{~m} / \mathrm{yr}$ for the period between 1986 and 1998.

- Fluvial supply was the dominant sedimentary process affecting the Mornos fan delta. Nowadays the fan delta can be considered partially inactive with coastal dynamic being the only process hat reworks the system.

- The only region where the fan delta progrades today is the area between the present mouth and Bouka Karahassani. A progradation rate of $3.4 \mathrm{~m} / \mathrm{yr}$ is estimated between 1945 and 1998 following the redistribution of the sediment derived from the erosion of the abandoned mouth and the eastern shores by longshore drift from the east.

- Although the main distributary prograded at a rate of about $4 \mathrm{~m} / \mathrm{yr}$ between 1945 and 1986 , a retreat of $11.4 \mathrm{~m} / \mathrm{yr}$ is observed between 1986 and 1998 due to the construction of the dam.

- It is expected that the shoreline retreat will accelerated in the near future due to the expected sea-level rise. The fan delta area that lies below $0.5 \mathrm{~m}$ will face severe inundation problems until 2100 estimated to be $2.58 \mathrm{~km}^{2}$ corresponding to $9.2 \%$ of the total fan delta 
area. An extensive part of the low-lying deltaic coastal plain, occupied by agricultural activities and marshes, will be seriously reduced.

\section{References}

Armijo, R., Meyer, B., King, G., Rigo, A., and Papanastassiou, D., 1996. Quaternary evolution of the Corinth Rift and its implications for the Late Cenozoic evolution of the Aegean, Geophys. J. Int., 126, 11-53.

Brooks, M., and Ferentinos, G., 1984. Tectonics and sedimentation in the Gulf of Corinth and the Zakynthos and Kefallinia Channels, western Greece, Tectonophysics, 101, 25-54.

Carte de la Grèce, 1852. Topographic Map of Greece, scale 1: 200000.

Gaki-Papanastassiou, K., Maroukian, H., Pavlopoulos, K., and Zamani, A., 1997. The implications of the expected sea-level rise on the low-lying areas of continental Greece in the next century, Proceedings of the International Symposium on Engineering Geology and the Environment, 121-126.

Galloway, W.E., 1975. Process framework for describing the morphological and stratigraphic evolution of deltaic depositional systems. In M. L. Broussard (ed.), Deltas, Models for Exploration. 87-98, Houston Geol. Soc., Houston.

Hasiotis, T., Papatheodorou, G., Bouckovalas, G., Corbau, C., and Ferentinos, G., 2002. Earthquake-induced coastal sediment instabilities in the Western Gulf of Corinth, Greece, Marine Geology, 186, 319-335.

Houghton, S.L., Roberts, G.P., Papanikolaou, I.D., McArthour, J.M., and Gilmour, M.A., 2003. New $234 \mathrm{U}-230^{\mathrm{Th}}$ coral dates from the western Gulf of Corinth: Implications for extensional tectonics, Geophys. Res. Lett., 30(19), 2013.

Hydrographical Service of the Navy, 1991. Tides and Tidal Data for Greek Harbours, $4^{\text {th }}$ edition, Athens. (in Greek)

I.P.C.C., 2001. Climate Change, Synthesis Report. (Stand-alone edition) - R.T. Watson and the Core Writing Team (eds), Geneva, 184pp.

K.u.K. Militär - Geographisches Institut, 1885. Topographic Map of Greece, scale 1: 200000.

Lascaratos, A., Salusti, E., and Papageorgaki, G., 1989. Wind-induced upwellings and currents in the Gulfs of Patras, Nafpactos and Korinthos, Western Greece, Oceanol. Acta, 12(3), 159164.

Maroukian, H., and Karymbalis, E., 2004. Geomorphic evolution of the fan delta of the Evinos river in western Greece and human impacts in the last 150 years, Zeitschrift für Geomorphologie N.F., 48(2), 201-217.

Piper, D.J.W., and Panagos, A.G., 1981. Growth patterns of the Acheloos and Evinos deltas, Greece, Sedimentary Geology, 28, 111-132.

Piper, D.J.W., Kontopoulos, N., Anagnostou, C., Chronis, G., and Panagos, A.G., 1990. Modern Fan Deltas in the Western Gulf of Corinth, Greece, Geo-Marine Letters, 10, 5-12.

Piper, D.J.W., Panagos, A.G., Kontopoulos, N., and Spiliotopoulou, M., 1982. Coastal Processes and Morphology, Gulf of Patras, Greece, Zeitschrift für Geomorphologie N.F., 26, 365-374.

Poulos, S.E., and Chronis, G.T., 1997. The importance of the river systems in the evolution of the Greek coastline, Bull. de l'Institut Océanographique, No special, 18, 75-96. 
Poulos, S.E., Collins, M.B., Pattiaratchi, C, Cramp, A., Gull, W., Tsimplis, M., and Papatheodorou, G., 1996. Oceanography and sedimentation in the semi-enclosed, deep-water Gulf of Corinth (Greece), Marine Geology, 134, 213-235.

Psilovikos, A., and Hahamidou, E., 1987. Contribution in the study of Greek Holocene deltas, Proceedings of the $2^{\text {nd }}$ Symposium of Oceanography, 456-463.

Stournaras, G., 1990. Etude géomorphologique et morphométrique du delta du Mornos (Grèce centrale). Possibilités de prévision du régime hydrogéologique, Besançon: Ann Sci Univ France-Compté 4, 5967.

Vött, A., Brückner, H., Schriever, A., Besonen, M., van der Borg, K. and Handl, M., 2004. Holocene coastal changes in the Acheloos alluvial plain (northwestern Greece) and their effects on the ancient site of Oiniadai, CIESM (Commission Internationale pour l'Exploration Scientifique de la mer Méditerranée) Workshop Contributions, 24, 33-42.

Zamani, A., and Maroukian, H., 1980. Deltaic sedimentation of the Sperchios River in historical times, Annales Géologiques des pays Helléniques, 30, 430-440. 